\begin{tabular}{|l|l|l||}
\hline \multicolumn{2}{|c|}{ PublisherInfo } \\
\hline \hline PublisherName & $:$ & BioMed Central \\
\hline \hline PublisherLocation & $:$ & London \\
\hline \hline PublisherImprintName & $:$ & BioMed Central \\
\hline \hline
\end{tabular}

\title{
A new nosocomial danger?
}

\begin{tabular}{|l|l|l||}
\hline \multicolumn{2}{|c||}{ ArticleInfo } \\
\hline \hline ArticleID & $:$ & 4160 \\
\hline \hline ArticleDOI & $:$ & $10.1186 /$ ccf-1999-2163 \\
\hline \hline ArticleCitationID & $:$ & 2163 \\
\hline \hline ArticleSequenceNumber & $:$ & 19 \\
\hline \hline ArticleCategory & $:$ & Paper Report \\
\hline \hline ArticleFirstPage & $:$ & 1 \\
\hline \hline ArticleLastPage & $:$ & 3 \\
\hline \hline & $:$ & RegistrationDate : 1999-10-27 \\
ArticleHistory & $:$ & OnlineDate $\quad$ 1999-10-27 \\
\hline \hline ArticleCopyright & $:$ & Current Science Ltd1999 \\
\hline \hline ArticleGrants & $:$ & \\
\hline \hline ArticleContext & $:$ & 1305422 \\
\hline \hline
\end{tabular}




\section{Keywords}

Critical illness, cross infection, gastritis, gastroduodenal hemorrhage, helicobacter

pylori, infection, intensive care units, nursing staff, serology, stress

\section{Comments}

These unexpected findings may have implications for the treatment of ICU patients. It may be shown in further trials that treatment of $H$ pyloriin these patients reduces the mortality and morbidity from gastrointestinal bleeding. If confirmed by other work, the possible pool for nosocomial infection in ICU nurses has important infection control implications.

\section{Introduction}

The gastrointestinal system is commonly affected by critical illness. Stress-related mucosal damage is frequently associated with increased mortality and morbidity in seriously ill patients. Damage is evident at endoscopy in most seriously ill patients within $24 \mathrm{~h}$ of admission to an intensive care unit (ICU).Helicobacter pylori infection is known to be the major pathogenic cause of chronic gastritis but its mode of transmission is unknown. The authors propose that $H$ pyloriinfection, or the inflammatory response by the host to this pathogen may contribute to the development of acute stress-related gastric mucosal damage.

\section{Aims}

To examine the relationship between H pylori serological status and stress ulceration in ICU patients. In addition the authors examined $H$ pylori serological status in ICU nurses which they propose as a measure of nosocomial infection.

\section{Methods}


This was a prospective, randomised study of 100 patients in an adult ICU. Nursing staff $(n=100)$ from the same ICU and blood donors $(n=500)$ were used as controls. H pylori serological status was measured and gastrointestinal bleeding in patients recorded.

\section{Results}

A total of $67 \%$ of ICU patients were seropositive for $H$ pylori and this was significantly higher than in controls. There was a trend in these seropositive patients toward increased macroscopic gastrointestinal bleeding. ICU nurses had a higher incidence of seropositivity for $\mathrm{H}$ pylori than in age matched controls. This was associated with duration of intensive care nursing.

\section{Discussion}

The high incidence of seropositivity for H pylori in ICU patients was unexpected. It may indicate that during critical illness $H$ pylori may alter the inflammatory response of the patient, which may then be associated with increased gastrointestinal bleeding. The surprising finding of high seropositivity in ICU nurses may be of more interest in elucidating the transmission route for H pylori. This has implications for the nurses themselves and may also represent a previously undetected nosocomial infection.

\section{References}

1. Robertson MS, Cade JF, Clancy RL: Helicobacter pylori infection in intensive care: Increased prevalence and a new nosocomial infection. Crit Care Med. 1999, 27: 1276-1280.

This PDF file was created after publication. 